\title{
Pengaruh pemberian ekstrak biji kakao (Theobroma cacao) terhadap jumlah pigmen melanin kulit tikus Wistar (Rattus novergicus) yang dipapar sinar matahari
}

\author{
${ }^{1}$ Koernia H. Yonathan \\ ${ }^{2}$ Poppy M. Lintong \\ ${ }^{2}$ Meilany F. Durry
}

\author{
${ }^{1}$ Kandidat Skripsi Fakultas Kedokteran Universitas Sam Ratulangi Manado \\ ${ }^{2}$ Bagian Patologi Anatomi Fakultas Kedokteran Universitas Sam Ratulangi Manado \\ Email: koernia.12283@gmail.com
}

\begin{abstract}
Excessive exposure of sunlight may cause hyperpigmentation. Cocoa is a beneficial plant to the skin. This study was aimed to reveal the effect of cocoa bean extracts on the number of melanin pigments in rat skin after sun exposure. This was an experimental study using 25 Wistar rats (Rattus norvegicus) divided into one control group and four treatment groups. The treatment consisted of sunlight exposure for one hour/day and application of cocoa bean extract $1600 \mathrm{mg} /$ day that varied among treatment groups. Group A was the negative control group (terminated at day 21). Group B, the treatment group 1, was exposed to sunlight for 30 days (terminated at day 31). Group C, the treatment group 2, was exposed to sunlight for 20 days (terminated at day 31). Group D, the treatment group 3, was divided into group D1 consisted of 2 rats and group D2 consisted of 3 rats. Group D1 was exposed to sunlight 30 minutes after the application of cocoa bean extract for 20 days (terminated at day 21). Group D2 was exposed to sunlight 30 minutes after the application of cocoa bean extract for 30 days (terminated at day 31). Group E was exposed to sunlight for 20 days and continued with the application of cocoa bean extract for the next 10 days (terminated at day 3). The results showed that sunlight exposure increased the number of melanin pigments in group B and C compared to group A. Group D showed fewer melanin pigments than group B and C. Group E showed fewer melanin pigments than group B, C, and D. Conclusion: Cocoa bean extract could reduce the number of skin melanin pigments in rats exposed to sunlight.
\end{abstract}

Keywords: cocoa beans extract, sunlight, melanin pigment, skin

\begin{abstract}
Abstrak: Paparan sinar matahari yang berlebihan dapat menyebabkan hiperpigmentasi. Kakao merupakan tanaman yang berkhasiat untuk pemeliharaan kesehatan kulit. Penelitian ini bertujuan untuk mengetahui pengaruh pengolesan ekstrak biji kakao dan pemaparan sinar matahari terhadap jumlah pigmen melanin kulit tikus Wistar. Jenis penelitian ialah eksperimental dengan menggunakan 25 tikus Wistar (Rattus norvegicus) yang dibagi menjadi satu kelompok kontrol dan empat kelompok perlakuan. Perlakuan yang diberikan ialah paparan sinar matahari selama 1 $\mathrm{jam} / \mathrm{hari}$ dan aplikasi ekstrak biji kakao dosis $1600 \mathrm{mg} / \mathrm{hari}$ yang bervariasi untuk masing-masing kelompok perlakuan. Kelompok A merupakan kontrol negatif (diterminasi hari ke-21). Kelompok B ialah kelompok perlakuan 1, diberi paparan sinar matahari selama 30 hari (diterminasi pada hari ke-31). Kelompok C ialah kelompok perlakuan 2, diberi paparan sinar matahari selama 20 hari (diterminasi hari ke-31). Kelompok D ialah kelompok perlakuan 3 yang dibagi menjadi kelompok D1 terdiri dari 2 tikus dan D2 dari 3 tikus. Kelompok D1 diberi paparan sinar matahari setelah diolesi ekstrak biji kakao 30 menit sebelumnya selama 20 hari (diterminasi hari ke-21). Kelompok D2 diberi paparan sinar matahari selama 1 jam setelah diolesi ekstrak biji kakao 30 menit sebelumnya selama 30 hari (diterminasi pada hari ke-31). Kelompok E ialah kelompok perlakuan 4 yang diberi paparan sinar matahari 20 hari dan dilanjutkan dengan pengolesan ekstrak biji kakao untuk 10 hari berikutnya (diterminasi hari ke-31). Hasil penelitian memperlihatkan bahwa kelompok $\mathrm{B}$ dan $\mathrm{C}$ menunjukkan peningkatan jumlah pigmen melanin
\end{abstract}


dibandingkan kelompok A. Kelompok D menunjukkan jumlah pigmen melanin yang lebih sedikit dibandingkan kelompok B dan C. Kelompok E menunjukkan jumlah pigmen melanin yang lebih sedikit dibandingkan kelompok B, C, dan D. Simpulan: Ekstrak biji kakao dapat mengurangi jumlah pigmen melanin kulit tikus Wistar yang dipapar sinar matahari.

Kata kunci: ekstrak biji kakao, sinar matahari, pigmen melanin kulit

Kakao banyak ditemukan di Indonesia dan Sulawesi merupakan daerah penghasil utamanya. ${ }^{1}$ Kakao merupakan salah satu tumbuhan yang kaya akan flavonoid dengan kandungan tertinggi pada bijinya. Konsumsi kakao yang kaya flavonoid akan meningkatkan aliran darah pada kulit, dan baik untuk pemeliharaan kesehatan kulit serta dapat memberikan efek perlindungan terhadap cahaya. $^{2}$

Terdapat sekitar 4000 jenis flavonoid yang dapat berperan sebagai penghambat proses pigmentasi pada kulit. Beberapa mekanisme penghambatan masih belum diketahui secara pasti namun mekanisme yang telah diterima secara umum yakni dengan menghambat kerja enzim tirosinase. ${ }^{3}$ Hambatan tersebut diperoleh dengan cara membentuk ikatan dengan enzim tirosinase dan melemahkan sifat katalisatornya sehingga mengurangi kemampuan katalisisnya dalam proses melanogenesis. ${ }^{4}$

Sinar matahari ialah sumber energi elektromagnetik yang terutama terdiri atas radiasi solar ultra violet dan spektrum infra merah. Spektrum ultra violet tersebut memiliki panjang gelombang antara 100$400 \mathrm{~nm}$ yang dibagi menjadi UVC, UVB, dan UVA. UVA memiliki panjang gelombang terpanjang dan disebut juga dengan UV gelombang panjang. Meski memiliki panjang gelombang terpanjang, aktivitas biologisnya lebih kurang dibandingkan dengan UVB. ${ }^{5}$ Manfaat sinar matahari bagi kesehatan manusia, antara lain: membantu proses pembentukan vitamin $\mathrm{D}$, mengurangi kolesterol dan gula darah, meningkatkan fungsi pernapasan, membantu proses pembentukan dan perbaikan tulang, serta dapat membunuh bakteri, virus, dan jamur. ${ }^{6}$

Meski diperlukan oleh sebagian besar makhluk hidup, paparan sinar matahari yang berlebihan akan menimbulkan dampak negatif pada kulit. Pada fase akut, paparan berlebihan akan mengakibatkan kerusakan DNA, eritema, mutasi, pigmentasi, dan imunosupresi. Dampak yang timbul bagi pigmentasi kulit yaitu meningkatnya aktivitas enzim tirosinase dalam melanogenesis. Hal ini dapat menyebabkan terjadinya hiperpigmentasi sehingga kulit menjadi lebih gelap. ${ }^{7,8}$

Tujuan penelitian ini ialah untuk mengetahui pengaruh pemberian olesan ekstrak biji kakao dan pemaparan sinar matahari terhadap jumlah pigmen melanin kulit tikus wistar.

\section{METODE PENELITIAN}

Jenis penelitian ini ialah eksperimental laboratorik yang dilakukan pada bulan September 2015 sampai Maret 2016 di Laboratoriun Patologi Anatomi Fakultas Kedokteran Universitas Sam Ratulangi Manado. Subyek penelitian ialah 25 ekor tikus wistar dewasa yang dibagi dalam 5 kelompok. Kelompok A (kontrol negatif), tikus tidak diberi perlakuan selama 20 hari dan diterminasi hari ke-21; kelompok B, tikus dipapar sinar matahari selama 1 jam/hari dalam 30 hari dan diterminasi hari ke-31; kelompok C, tikus tikus dipapar sinar matahari selama 1 jam/hari dalam 20 hari dan diterminasi hari ke-31; kelompok $\mathrm{D}$, dibagi menjadi $\mathrm{D} 1$ yang berisi 2 tikus dan D2 yang berisi 3 tikus. Tikus kelompok D1 dipapar sinar matahari selama 1 jam/hari dalam 20 hari setelah diberi olesan ekstrak biji kakao 30 menit terlebih dahulu dan diterminasi hari ke-21; kelompok D2, tikus dipapar sinar matahari selama 1 jam dalam 30 hari setelah diberi olesan ekstrak biji kakao 30 menit terlebih dahulu dan diterminasi hari ke-31. Kelompok E, tikus dipapar sinar matahari selama 20 hari kemudian dilanjutkan pemberian olesan ekstrak biji kakao 10 hari berikutnya dan 
diterminasi hari ke-31.

Organ kulit tikus kontrol dan perlakuan diproses untuk pembuatan preparat histopatologik dan dievaluasi gambaran jumlah pigmen melanin kulit. Jumlah pigmen melanin yang dihitung ialah pigmen melanin yang terlihat per satu lapangan pandang, pembesaran microskopik 100x10, dengan interpretasi dibagi 3 kategori: sedikit ( $<40$ pigmen melanin), sedang (40-80 pigmen melanin), dan banyak ( $>80$ pigmen melanin).

Ekstrak biji kakao (Theobroma cacao) yang digunakan ialah hasil ekstrak biji kakao yang dibuat di Laboratorium Farmasi Fakultas MIPA Universitas Sam Ratulangi Manado. Dosis yang digunakan yaitu 1600 mg/tikus/hari. Ekstrak biji kakao dilarutkan menggunakan aquades 1,6 $\mathrm{ml}$ lalu diberikan secara topikal pada punggung tikus yang sebagian bulunya telah dicukur. ${ }^{9}$

\section{HASIL PENELITIAN \\ Kelompok A}

Kelompok A ialah kelompok tikus tanpa perlakuan dan diterminasi pada hari ke-21. Gambaran pigmen melanin kulit tikus Wistar yang terdapat pada epidermis tikus di kelompok ini sedikit. Jumlah pigmen melanin kulit yang tampak <40 butir (Gambar 1).

\section{Kelompok B}

Kelompok B diberi paparan sinar matahari selama 1 jam/hari dalam 30 hari. Tikus diterminasi pada hari ke-31. Pada kelompok ini pigmen melanin kulit yang tampak pada epidermis lebih banyak daripada kelompok kontrol. (Gambar 2).

\section{Kelompok C}

Kelompok C diberi paparan sinar matahari selama 1 jam/hari dalam 20 hari. Tikus diterminasi pada hari ke-31. Pada kelompok ini ditemukan satu tikus yang memiliki jumlah pigmen melanin pada epidermis $>80$ butir sedangkan tikus yang lain memiliki jumlah pigmen melanin yang kurang dari 40 butir. (Gambar 3).

\section{Kelompok D}

Kelompok D diberi olesan ekstrak biji kakao terlebih dahulu sebelum diberi paparan sinar matahari. Dua tikus diterminasi pada hari ke-21 (Gambar 4), sedangkan sisanya pada hari ke-31. Salah satu tikus pada kelompok ini mengalami peningkatan pigmentasi sedang (Gambar 5).

\section{Kelompok E}

Kelompok E diberi paparan sinar matahari selama 1 jam/hari dalam 20 hari kemudian dilanjutkan dengan pemberian ekstrak biji kakao pada hari ke-21 sampai ke-30. Tikus diterminasi pada hari ke-31. Jumlah pigmen melanin yang tampak pada epidermis kurang dari 40 butir (Gambar 6).
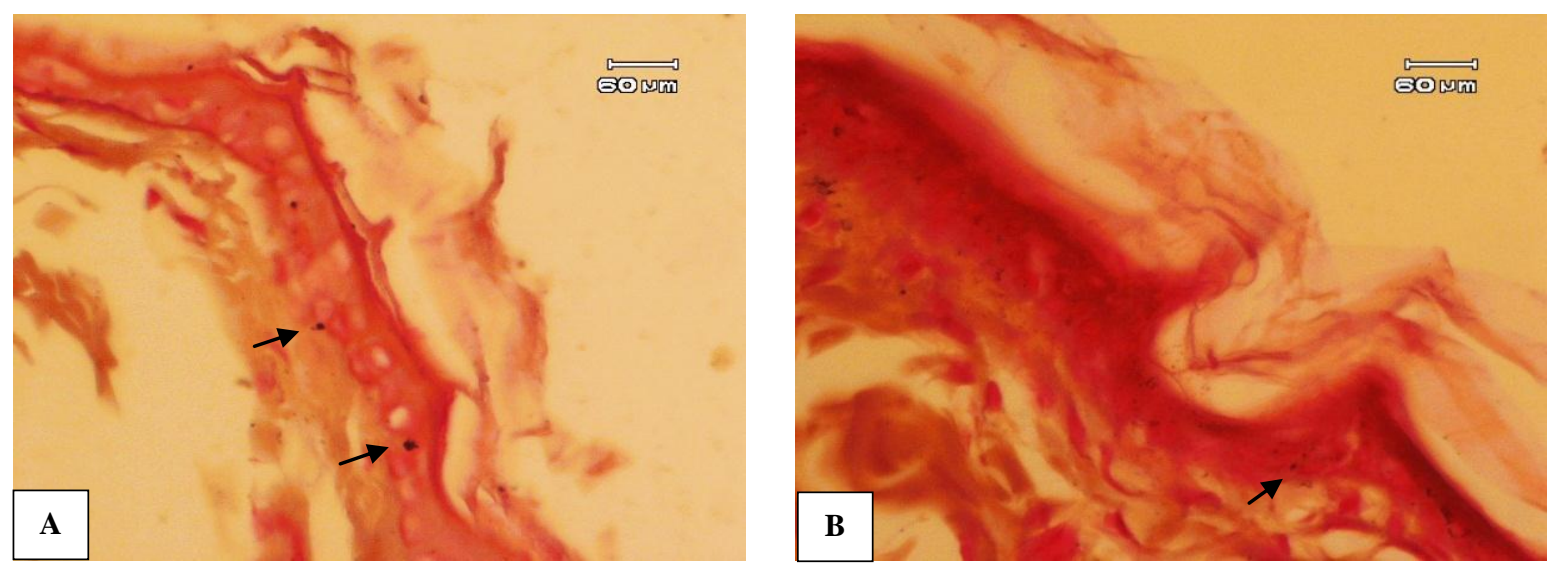

Gambar 1. Gambaran mikroskopik kulit tikus wistar kelompok A (kontrol negatif). Pigmen melanin kulit yang tampak pada epidermis kulit tikus berjumlah sedikit (panah hitam) (Gambar A dan B, pembesaran 400x). 

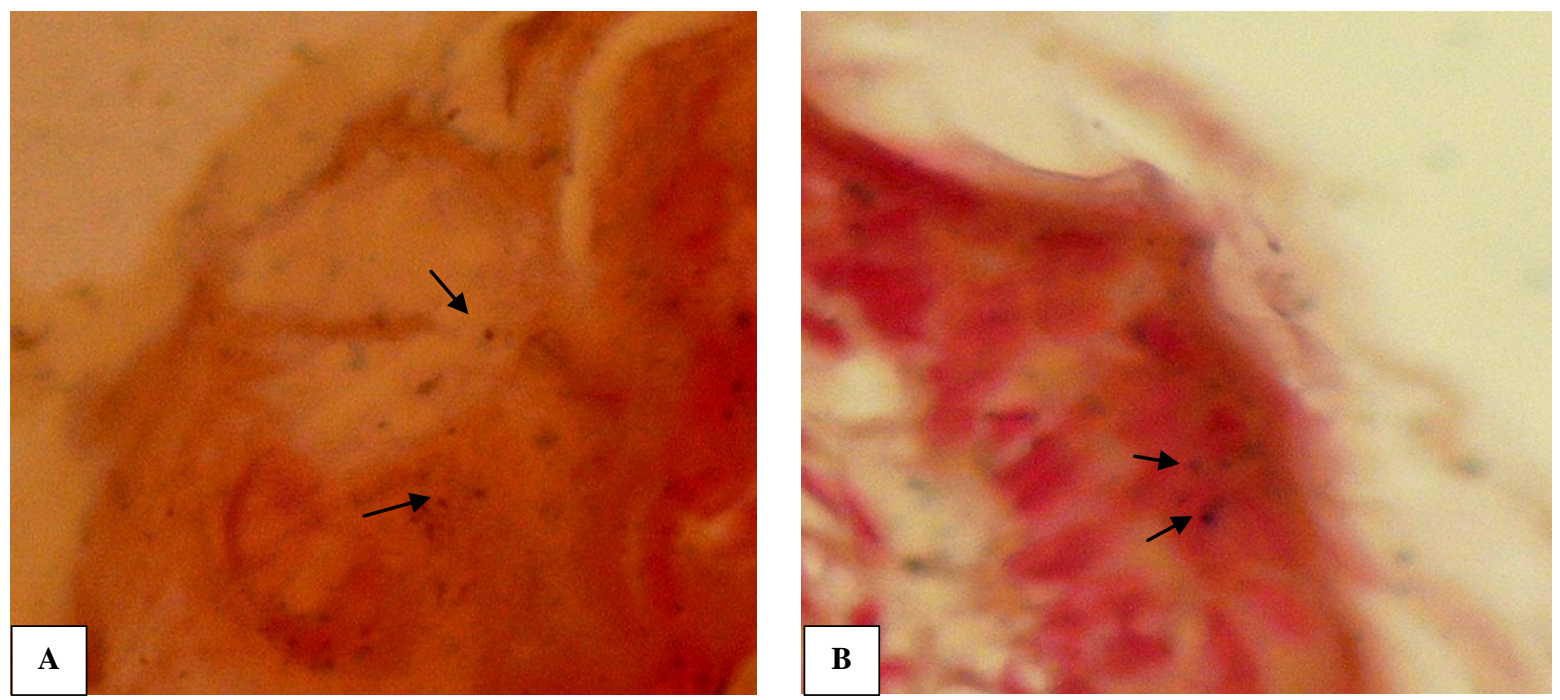

Gambar 2. Gambaran mikroskopik kulit tikus kelompok B (perlakuan 1). Terdapat peningkatan pigmentasi yang sedang pada Gambar A dengan jumlah pigmen melanin pada epidermis yang mencapai lebih dari 40 butir, sedangkan pada Gambar B kurang dari 40 butir (panah hitam) (pembesaran 400x).
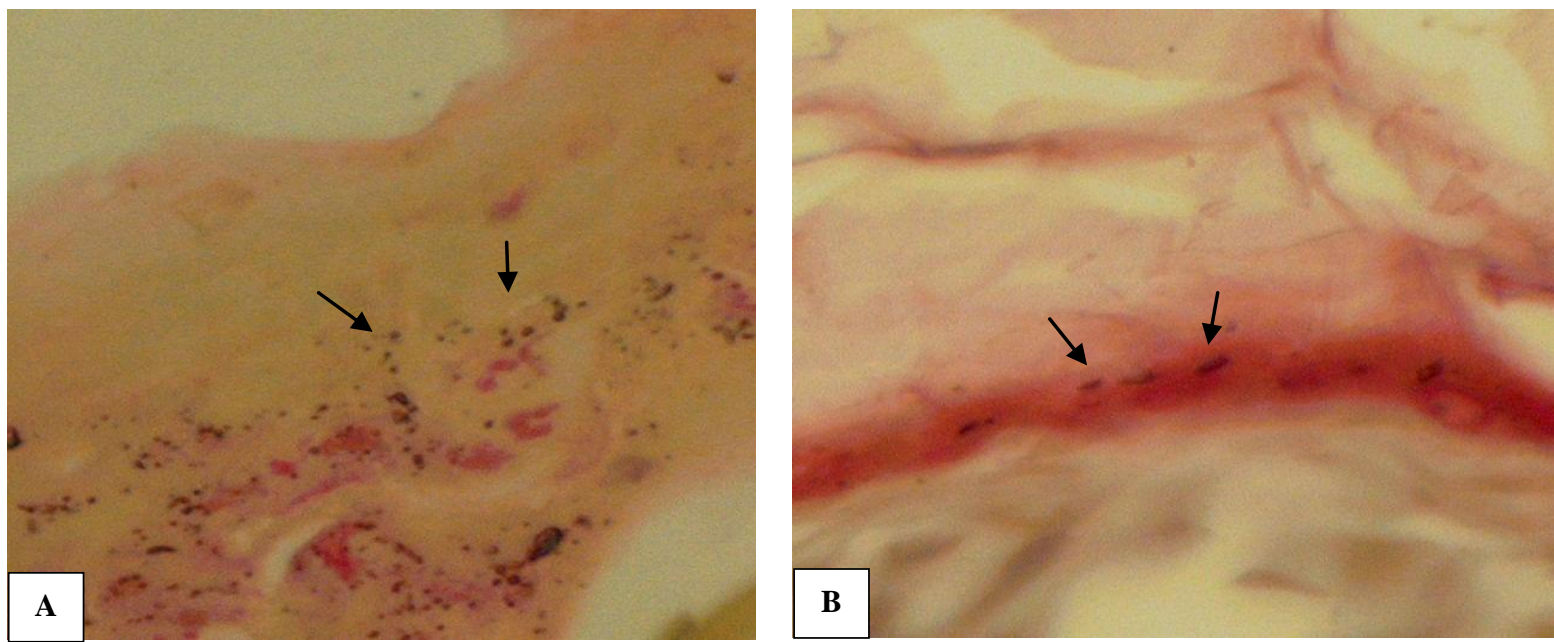

Gambar 3. Gambaran mikroskopik kulit tikus kelompok C (perlakuan 2). Tampak pigmen melanin di epidermis dalam jumlah banyak pada Gambar A (panah hitam). Gambar B memiliki jumlah pigmen melanin yang kurang dari 40 butir (panah hitam) (pembesaran 400x).
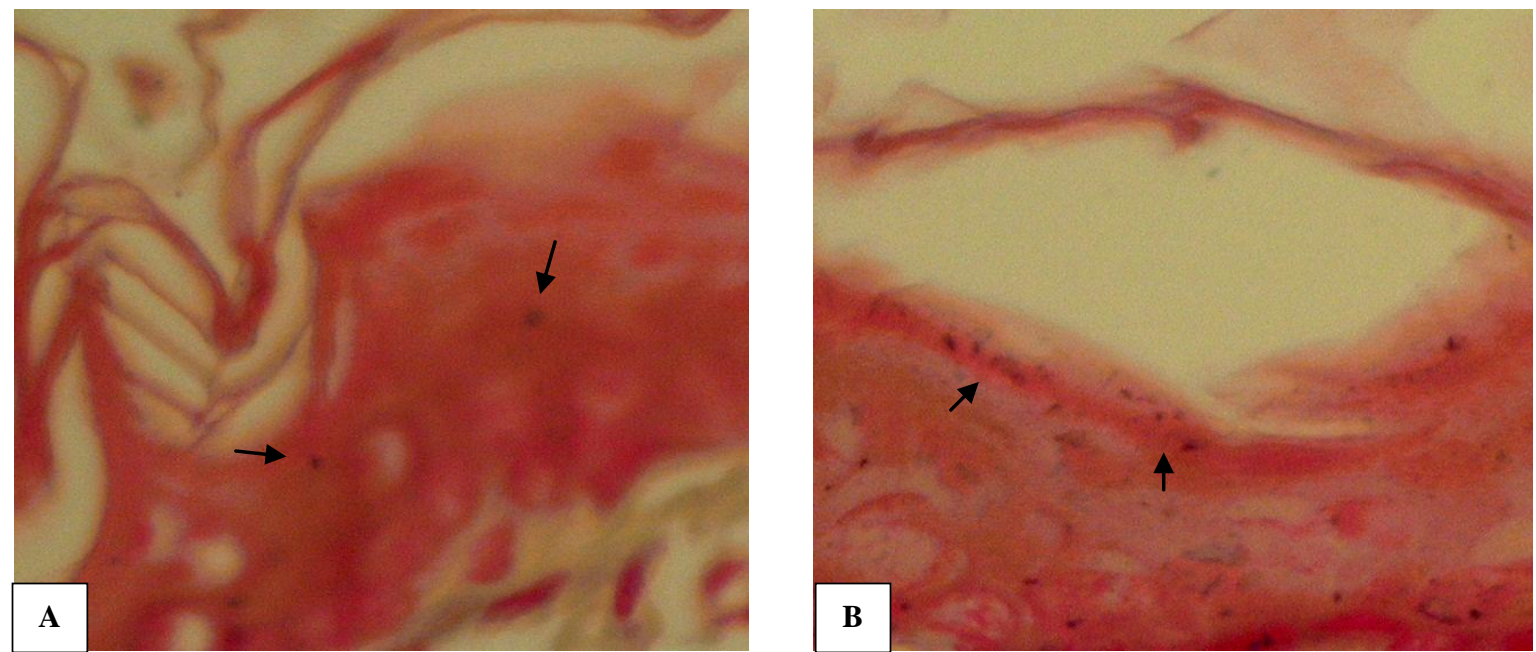

Gambar 4. Gambaran mikroskopik kulit tikus kelompok D (perlakuan 3) yang diterminasi hari ke-21. Pada Gambar B terlihat sejumlah besar pigmen melanin pada epidermis namun masih di bawah 80 butir (panah hitam). Pigmen melanin pada Gambar A tampak sangat sedikit (pembesaran 400x). 

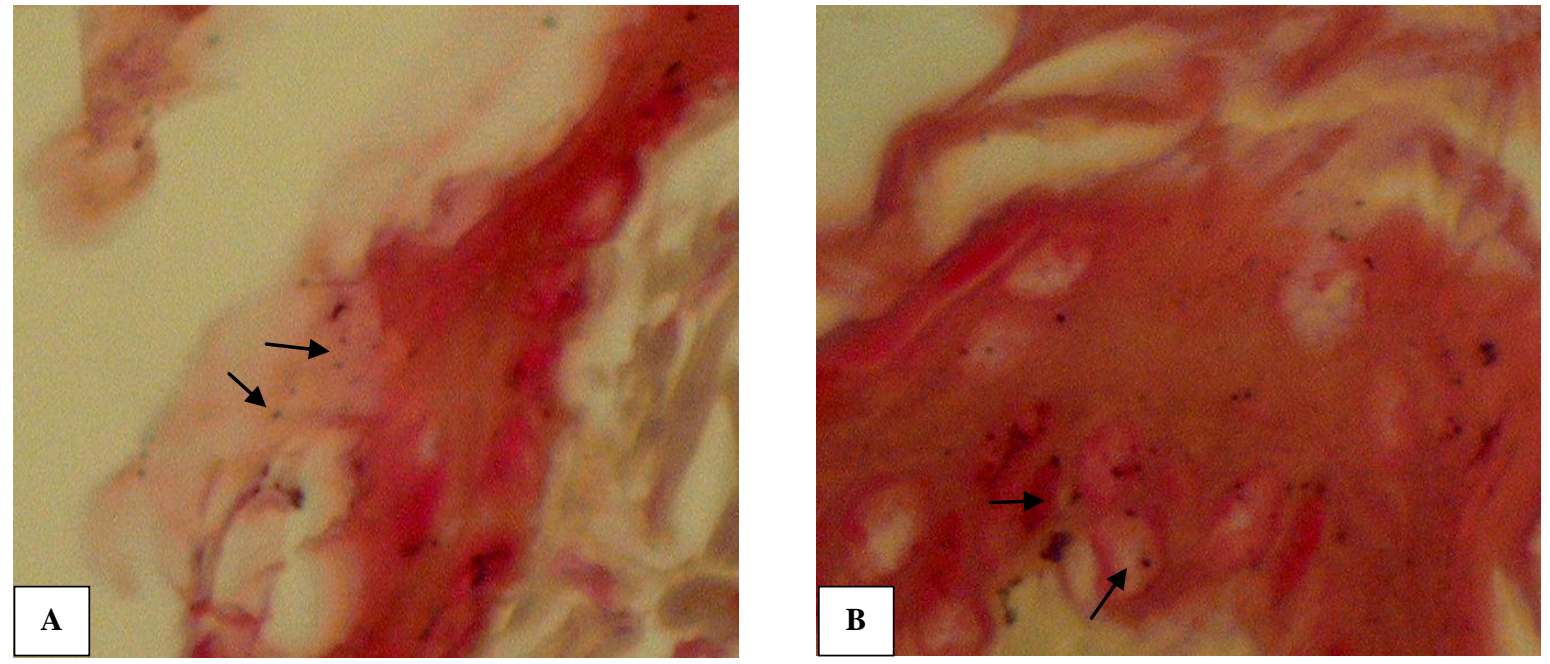

Gambar 5. Gambaran mikroskopik kulit tikus kelompok D (perlakuan 3) yang diterminasi hari ke-31. Jumlah pigmen melanin yang tampak di epidermis kurang dari 40 butir (panah hitam) (pembesaran 400x).
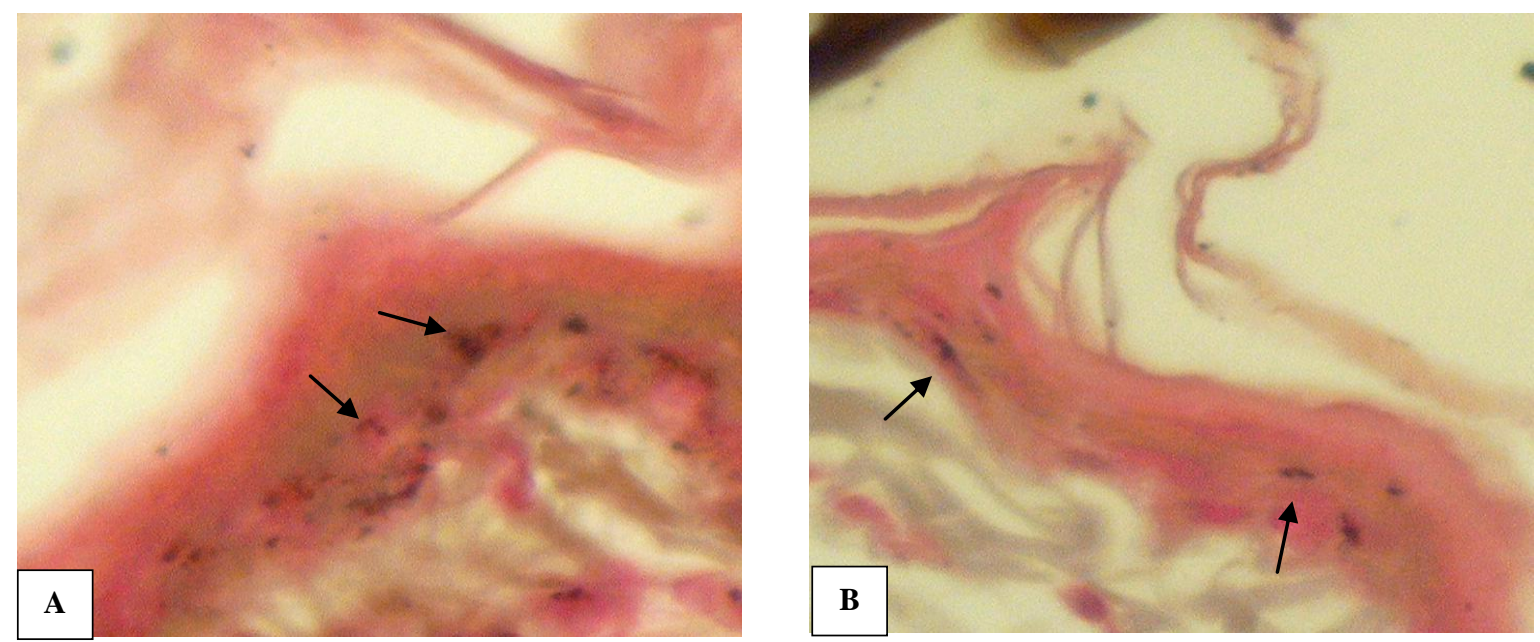

Gambar 6. Gambaran mikroskopik kulit tikus kelompok E (perlakuan 4). Tampak adanya sedikit peningkatan pigmentasi di semua gambar dengan jumlah pigmen melanin yang tampak di epidermis kurang dari 40 butir (panah hitam) (pembesaran 400x).

\section{BAHASAN}

Perubahan warna pada kulit dapat disebabkan oleh berbagai faktor, salah satunya ialah radiasi ultraviolet dari paparan sinar matahari yang berlebihan. ${ }^{10}$ Meski perubahan warna tersebut merupakan hasil dari melanogenesis sebagai mekanisme pertahanan tubuh terhadap radiasi UV, ${ }^{11}$ jika dibiarkan secara terus-menerus akan mengakibatkan hiperpigmentasi pada kulit. ${ }^{7}$ Penelitian yang dilakukan ini memberikan informasi mengenai pengaruh paparan sinar matahari dan pemberian ekstrak biji kakao terhadap jumlah pigmen melanin kulit tikus wistar dengan membandingkan kelompok kontrol dan kelompok perlakuan.

Pada tikus wistar kelompok kontrol negatif didapatkan nilai rata-rata jumlah pigmen melanin sangat kecil. Kelompok B yang diberi paparan sinar matahari selama 1 jam/hari dalam 30 hari memiliki jumlah rata-rata tertinggi dibandingkan kelompok yang lain. Paparan sinar matahari yang diterima meningkatkan aktivitas enzim tirosinase yang mengkatalisis reaksi hidroksilasi dari tirosin menjadi dihyroxyphenylalanine (DOPA) dan oksidasi dari DOPA menjadi Dopaquinone. ${ }^{12}$ Peningkatan aktivitas ini menyebabkan terjadinya peningkatan produksi pigmen melanin pada kulit. Peningkatan produksi melanin oleh 
melanosit ini merupakan bentuk pertahanan utama organ kulit terhadap radiasi UV dari sinar matahari. ${ }^{7}$

Kelompok yang diberi paparan sinar matahari selama 20 hari dan tak diberi perlakuan selama 10 hari menunjukkan hasil yang lebih rendah dibandingkan dengan kelompok yang mendapat paparan sinar matahari selama 30 hari. Hal ini menunjukkan intensitas paparan yang didapat turut berpengaruh pada produksi pigmen melanin. Semakin tinggi intensitas paparan yang didapat semakin tinggi pula jumlah pigmen melanin yang diproduksi melanosit. Hasil ini juga menunjukkan adanya proses fisiologi kulit yang menurunkan produksi pigmen melanin setelah paparan tidak diberikan. Diperlukan penelitian lebih lanjut mengenai hal tersebut.

Kelompok yang diberi olesan ekstrak biji kakao sekitar 30 menit sebelum dipapar sinar matahari menunjukkan hasil yang termasuk kategori sedikit. Nilai rata-rata pigmen melanin kulit pada kelompok ini ialah 20. Hasil ini lebih rendah dibandingkan dengan kelompok $\mathrm{B}$ dan $\mathrm{C}$ yang masuk dalam kategori sedang. Hal ini menunjukkan peranan flavonoid pada ekstrak biji kakao yang menghambat kerja enzim tirosinase melalui ikatan yang terbentuk dengan enzim tersebut. Ikatan ini melemahkan sifat tirosinase sebagai merupakan katalisator sehingga menurunkan efektivitasnya dalam katalisis reaksi hidroksilasi dari tirosin menjadi DOPA dan oksidasi dari DOPA menjadi Dopaquinone. ${ }^{4}$ Pemberian ekstrak sekitar 30 menit sebelum pemberian paparan sinar matahari bertujuan untuk memaksimalkan efek proteksi terhadap radiasi UV. Hasil yang didapatkan kelompok perlakuan tersebut menunjukkan ekstrak kakao juga memiliki efek tabir surya. ${ }^{9,13}$

Kelompok E menunjukkan jumlah pigmen yang lebih sedikit dibandingkan kelompok C dan D. Hasil ini menunjukkan adanya peranan ekstrak biji kakao dalam membantu mempercepat penurunan produksi pigmen melanin pada kulit. Kandungan flavonoid yang tinggi dalam biji kakao dapat berperan sebagai antioksidan atau reduktor pada sintesis melanin yang membutuhkan oksigen. Penurunan produksi melanin pada kelompok ini juga dapat disebabkan oleh proses fisiologi kulit setelah dihentikan dengan paparan sinar matahari selain karena peranan ekstrak biji kakao sendiri. Hal ini memerlukan penelitian lebih lanjut. Hasil yang diperoleh dari dua kelompok yang menggunakan ekstrak biji kakao ini sejalan dengan penelitian yang dilakukan oleh Adriani pada tahun 2015 tentang efek proteksi dan antioksidan dari ekstrak kakao terhadap kulit mencit yang dipapar radiasi UV. ${ }^{9}$

Berdasarkan penelitian ini ekstrak biji kakao dengan kandungan flavonoid yang tinggi diperkirakan dapat memengaruhi jumlah pigmen melanin kulit tikus wistar yang dipapar sinar matahari berupa adanya penurunan nilai rata-rata pigmen melanin kulit sebelum dan sesudah diberi paparan sinar matahari.

Keterbatasan dari penelitian ini ialah kurangnya waktu penelitian untuk mengetahui pengaruh pemberian paparan sinar matahari dan ekstrak biji kakao terhadap kulit dalam jangka waktu yang lebih panjang. Faktor lain yang turut memengaruhi penelitian ini ialah cuaca berawan yang mengakibatkan sinar matahari menjadi kurang terik dan sering hujan. Namun demikian, hasil penelitian ini dapat menambah informasi dan pengetahuan mengenai efek positif ekstrak biji kakao terhadap kesehatan terutama kesehatan organ kulit dan mengembangkan penelitian-penelitian yang berhubungan dengan tanaman kakao.

\section{SIMPULAN}

Dari hasil penelitian dan bahasan dapat disimpulkan bahwa paparan sinar matahari menyebabkan terjadinya peningkatan jumlah pigmen melanin pada kulit tikus Wistar. Pemberian ekstrak biji kakao dapat mengurangi jumlah pigmen melanin pada kulit tikus Wistar yang dipapar sinar matahari. 


\section{SARAN}

1. Perlu penambahan jangka waktu perlakuan dalam penggunaan ekstrak biji kakao untuk memperoleh hasil yang optimal

2. Perlu dilakukan penelitian lebih lanjut mengenai kandungan flavonoid dalam biji kakao

3. Perlu mempertimbangkan faktor cuaca terutama dalam penelitian yang menggunakan sinar matahari

4. Perlu hewan coba yang lebih tahan uji karena tikus Wistar mudah mati dan sangat tidak tahan terhadap stres (sinar matahari) yang diberikan

\section{DAFTAR PUSTAKA}

1. Saragih R. Kakao Indonesia: Optimis nomor satu di dunia. Online Mei 27, 2013. [cited: Mei 13, 2016]. Available from:http://ditjenbun.pertanian.go.id/ bbpptpmedan/berita-179-kakaoindonesia--optimis-nomor-satudidunia.html.

2. Ismawan $B$, Syariefa E, Untung $O$, Karjono, Utami PK, Duryatmo S, et al. Ragam tanaman Indonesia berkhasiat. Bahrudin MA, editor. 100 Plus Herbal Indonesia. Depok: PT Trubus Swadaya, 2015;p. 264-71.

3. Baumann L. Nonsurgical skin care and rejuvenation. In: Gurtner GC, Neligan PC. Plastic Surgery (3rd ed). China: Elsevier, 2013; p. 25.

4. Chang TS. An updated review of tyrosinase. NCBI. [Online] Juni 2009. [cited: November 8, 2016]. Available from: https://www.ncbi.nlm.nih.gov/pmc/ar ticles/PMC2705500/.

5. Soebaryo R, Jacoeb T. Fotobiologi. In: Menaldi SL, Bramono K, Indriatmi W. Ilmu Penyakit Kulit dan Kelamin (7th ed). Jakarta: Badan Penerbit FKUI, 2015; p. 202.
6. Adoe D. Perbedaan fragilitas eritrosit antara subyek yang jarang. [Online] 2006. [Cited: Oktober 8, 2015]. Available from: http://eprints.undip.ac.id/ 21398/1/Desmiyati.pdf.

7. Kabulrachman. Kelainan Pigmen (1st ed). Harahap M, Rachmah L, Cahanar P. editors. Jakarta: Hipokrates, 2000; p. 146.

8. Baumann L. Skin Types. In: Saghari S, Weisberg E, editors. Cosmetic Dermatology (2nd ed). New York : McGraw-Hill, 2009; p. 98.

9. Adriani A. Analisis ekspresi 8-OHdG, PCNA, dan hiperplasia epidermis pada kulit mencit yag mendapat ekstrak kakao topikal dan paparan UVB. Online Februari 11, 2015. [Cited: November 8, 2016]. Available from: http://repository.unhas.ac.id: 4002/digilib/gdl.php?mod=browse\&o $\mathrm{p}=$ read\&id=--disertasia- $12969 \&$ PHPSESSID $=\mathrm{f} 528421 \mathrm{bf} 0 \mathrm{dc} 3 \mathrm{de} 9 \mathrm{~d} 7 \mathrm{c} 9$ 1897eaa649fc.

10. Layuck A, Lintong PM, Loho L. Pengaruh pemberian air perasan jeruk nipis (Citrus aurantifolia). eBm. 2015;3:1-2.

11. Baumann L, Sogol S. Skin pigmentation and pigmentation disorders. Saghari $\mathrm{S}$, Weisberg E, editors. Cosmetic Dermatology 2. New York: McGraw-Hill, 2009; p. 100-1.

12. Nip J, Potterf S, Rocha S, Vora S, Bosko C. The New Face of Pigmentation and Aging. In: Miranda FA, Kenneth MW, Howard MI, ediotrs. Textbook of Aging Skin (1st ed). Berlin: Springer, 2010; p. 509-12.

13. Baumann L. Sogol S. Sunscreens. In: Saghari S, Weisberg E, Sydor A, editors. Cosmetic Dermatology (2nd ed). New York: McGraw-Hill, 2009; p. 76 . 